How to Cite

Esha, -. (2019). A study on effectiveness of training and development programs. International Journal of Business, Economics \&

Management, 2(1), 11-17. https://doi.org/10.31295/ijbem.v2n1.62

\title{
A Study on Effectiveness of Training and Development Programs
}

\author{
Esha \\ PTU, Jalandhar, India \\ Email:eshamehta6@gmail.com
}

\begin{abstract}
The Indian banking industry is endlessly going through a process of transformation since the nineties, due to the introduction of Liberalization, Privatization and Globalization (LPG), Information and Communication Technology (ICT). Therefore in order to sustain the economic and effective performance of Human Resource, it is important to optimize their contribution to the achievement of the aims and objectives of the organization through training and development. This paper main objective is to examine the level of performance in terms of imparting training. The second objective is to examine the effectiveness of training and development programs for employees in fulfillment of their duties. A present research paper is of descriptive type and based on primary data collected through questionnaire filled by the bank employees. The data have been checked through statistical software to find the impact of training and development on employees' performance. There are two variable Training and Development (Independent) and Employees' performance (Dependant). The present paper explained that training and development are inevitable and unavoidable. Anyone can cope up with the existing challenges in the wake of severe competition with training and development only.
\end{abstract}

Keywords---banks, employees, human resource management, performance, training and development.

\section{Introduction}

"The ergonomics of the work environment, state of the art equipment as well as quality raw materials can make production possible, but it is the human resources that actually make the production happen", Asare-Bediako (2008).

Human resources are a crucial but expensive resource and therefore in order to sustain the economic and effective performance of this resource, it is important to optimize their contribution to the achievement of the aims and objectives of the organization through training and development. Training is, therefore, necessary to ensure an adequate supply of employees that are technically and socially competent for both departmental and management positions. (Mullins, 2007)

\section{Training \& Development}

In early age especially after 2nd world war the organization have come to know that without training they cannot get success, then the organizations started emphasizing on training, First organizations in United State started giving training to their employee, In the 1910s, some corporations (General Electric, Westinghouse, International Harvester) were having factory schools to train their employees in order to develop their technical skills as they realized the importance of training and development. Although few researchers disagree about the importance of training and development on the success of an organization because it involves a huge cost that may affect prioritization (Pérez et al., 2018; Sawali, 2018; Wartawan, 2017).

Training plays a significant role in achieving organizational objectives by keeping in view the interest of employees and organization (Stone J.R. human resource 2002). To achieve the organizational goals employee performance is important that depends on a variety of factors. But training receives high importance as it improves the skills, capabilities, confidence, and competencies. Training includes 'soft' skills such as software training, management training. Whereas development focuses upon the activities that enhance employee skills for the future. Employee development is a long term process that comprises, mentoring, succession planning, coaching, etc.

ISSN 2632-9476

Received Jan 20, 2019 / Accepted Jun 18, 2019 / Published Jul 05, 2019 
In short, to achieve the organization goals role of human capital leads to organizational growth and development and human capital is totally related with training, if your employee is trained he/she can better perform in organizations. The main purpose of our study is to determine the effect of training and development on organizational performance. Organizations should focus more on training than on cost control and efficiency because the organization cannot get effectiveness without training and development.

Training: The aim of any training program is to provide instruction and experience to new employees to help them reach the required level of performance in their jobs quickly and economically. For the existing staff, training will help develop capabilities to improve their performance in their present jobs, to learn new technologies or procedures, and to prepare them to take on increased and higher responsibilities in the future (Suparsa et al., 2017; Sulistiawati et al., 2017).

Development: Employee Development Programs are designed to meet specific objectives, which contribute to both employee and organizational effectiveness. There are several steps in the process of management development. These include reviewing organizational objectives, evaluating the organization's current management resources, determining individual needs, designing and implementing development programs and evaluating the effectiveness of these programs and measuring the impact of training on participants quality of work life.

\section{Definitions of Training and Development}

According to Michel Armstrong, "Training is systematic development of the knowledge, skills, and attitudes required by an individual to perform adequately a given task or job".

According to the Edwin B Flippo, "Training is the act of increasing knowledge and skills of an employee for doing a particular job."

Dale S Beach defined "Training is usually considered as the organized procedure by which people gain knowledge and increase skill for a definite purpose"

\section{Differences between Training and Development}

Employee training is different from management development or executive development. While the former refers to the training given to employees in the operational, technical and allied areas, the latter refers to developing an employee in the areas of principles, and techniques of management, administration, organization and allied ones.

Table 1

Area training development

\begin{tabular}{lll}
\hline \multicolumn{1}{c}{ Area } & \multicolumn{1}{c}{ Training } & \multicolumn{1}{c}{ Development } \\
\hline Content & Technical skills and knowledge & Managerial Behavioral skills and knowledge \\
Purpose & Specific and Job-related & Conceptual and General Knowledge \\
Duration & Short term & Long term \\
For Whom & Technical and non-managerial personnel & Managerial personnel \\
\hline
\end{tabular}

\section{Training and Development in Banks}

In Banks, there is a need for the continuous training and development of the staff in the areas of customer care services on operational aspects and behavioral aspects of the business. How are the needs identified? The training needs are assessed through task analysis and performance analysis, which can be conducted through surveys, or from the information furnished by the heads of the departments, customer complaints, even from the reports on 360degree feedback systems. In case of a large banks, there are two ways of conducting training programmes - through an established department having a full time HRD functionary who oversees all the training and development functions of the Banks or through an external trainers coordinated by the HRD department These days Banks have recognized the need for training and re-training their staff, in order to develop a competitive edge over their competitors in delivering high-quality services to the customers.

Traditionally, banks have recruited young school leavers, and their initial training was either long apprenticeship or on-the-job or formal training in basic routine operations. Aspirants to management position were encouraged to qualify professionally by reading for associate-ship of the Institute of Bankers or an equivalent qualification. It was argued that banking requires the exercise of sound training and development programs for their employees. 


\section{Literature Review}

According to Heath field (2012), the right employee training, development, and education at the right time, provides big payoffs for the organization to increase productivity, knowledge, loyalty and contribution.

Baldwin \& Johnson (1995), claim that lower levels of training will increase the chances of employee migration from one organization to another. However, employee's satisfaction and loyalty increases by a higher degree of training towards the firm and decreases the chances of employee termination. (Choo \& Bowley, 2007).

Jadhav (2013), studied the training and development programs undertaken by banks for their employees. The main objectives of the present study were to analyze the effectiveness of training and development programs for employees to discharge their duties and to study how training and development programs help to achieve customer satisfaction. For this study primary data was collected through questionnaire filled by the bank employees. A sample of 40 employees is selected by the use of random sampling from different banks like HDFC, ICICI, Vijaya Bank, Bank of Baroda, and Dena Bank located in the suburban area of Mumbai. It is concluded that private and public Indian banks undertake training and development programs for their employees to increase their efficiency. Banks provide training programs to enhance their knowledge and skills to satisfy the customers. Growth of banking sector in India is the result of skilled manpower which is the outcome of training and development.

Training and development have a significant role in the development of employee's performance. According to Partlow, (1996); Tihanyi et al., (2000) and Boudreau et al., (2001), training should be designed according to the need of employee and organizations which perform these things get better results. The design of training should be according to the needs of the employees (Ginsberg, 1997).

Ramakrishna et al., (2012), have studied that the Human Resource Development department has to play a more proactive role in shaping the employees to fight out the challenges. The banks not only have to make plans and policies and devise strategies, but the actual functionaries also have to show competence and effectiveness in executing the said policies and strategies. A sample of 85 employees covering all Canara bank branches in Kurnool District has been considered for the study at random. The study revealed that the employees have attended more training and development programs, employees strongly agreed about the necessity of training and development programs, majority of the employees rated trainer's preparation as good, employees rated trainers creating learning atmosphere and employees given an overall rating for training and development programs.

Sthapit (2012), pointed out that the strategic human resource development factors affecting the evaluation of induction training effectiveness in Nepali banks. The study was based on the survey which was conducted during Feb-March 2012 on 104 low and middle-level managers of Nepali development banks established from June 2001 to June 2010. The study revealed that induction training as most effective in terms of learning and least effective on the behavior change criterion.

Purohit (2012), studied the existing policies practiced in co-operative banks to appraise the level of HRD practices, to assess the satisfaction level of employees about HRD practices particularly Training and development \& Reward and recognition of employees. In the present study structured questionnaire via in-depth personal interviews is used to collect primary data. From a large number of banks in Pune region, 16 are selected for the study. Information was collected from 30 employees of different level. The study adopted random sampling with regard to the selection of cooperative banks. The study revealed that training helps employees to gain a better understanding in the area of Job and this will enhance their stock of knowledge. Extensive training providing continuous development, such as on-the-job training, training programs and workshops can be a driving factor for the activities in the firm. The present paper also suggests the ways $\&$ means by which the selected co-operative banks can improve their high performances of work practices.

Srimannarayana (2011), in his study, found that Training and Development is a very important component in the modern Human Resource Management and the scope of training and development vary from one organization to another. The present study is based on primary data. Data is collected from $105 \mathrm{HR} /$ Training professionals working in manufacturing, IT/ITES and service sector with a minimum experience of three years in their respective organization in the functional area of training and development. The study revealed that more than $75 \%$ of respondents have believed that performance improvements made because of training are an extremely valuable measure and $70.48 \%$ have believed that transfer of learning is extremely important. Almost (95.24\%) respondents have mentioned that they collect feedback of the participants after completion of the training program routinely. There is a gap between the measures that that are used actually in assessing training and development and HR/Training professionals do not have control over data that is required for measuring training and development.

Nagar (2009), study the effectiveness of training programs being conducted by the commercial banks in public as well as in the private sector. The area of study is limited to the staff training centers of State Bank of Bikaner \& Jaipur and The Bank of Rajasthan Ltd. The data is collected through a structured questionnaire containing several 
questions relating to various aspects of the training program. The focus of the study is mainly the opinions of the trainees regarding various aspects of training like course duration, library facilities, trainer, teaching \& computeraided program and other infrastructural facilities and the calculated $t$ values is less than table value of $t$, hence null hypothesis is accepted or hence there is no significant difference in the opinion of respondent at the two staff training centers.

According to Ivancevich (2010), training and development is a process that attempts to provide employees with information, skills, and understanding of the organization and its goals. Additionally, training and development aid an employee to continue to make the necessary positive contribution to the success of employing organization in terms of his / her good performance on the job. To start this whole process is orientation and socialization of employees into the organization.

Cole (1997), says further that training and development are faced by every organization, even though the quality and intensity of the training carried out may from one organization to another. He goes on to list the factors that tend to influence the quality and quantity of the training and development activities of various organizations as follows:

a) That the degree of change in the external environment e. g. technology, legislation and so on has an influence on training and development.

b) That degree of internal change e. g. new processes, new markets, new competitors, have an effect

c) The availability of suitable skills within the existing workforce

d) The adaptability of the existing workforce

e) The extent to which the organization supports the idea of internal career development

f) The commitment of senior management to training as an essential part of economic success

g) The extent to which management sees training as a motivating factor in work and finally

h) Knowledge and skills of those responsible for carrying out the training.

\section{Objectives}

a) To examine the level of performance in terms of imparting training.

b) To investigate the effectiveness of training and development on employees performance as in the fulfilment of their duties.

Taking these objectives in observation, we postulate that training is positively related to the job performance of employees.

\section{Research Methodology}

The present study used descriptive statistics to measure the level of perception across all understudy variables and it is based on primary data collected through questionnaire filled by the 105 bank employees which show the response on 5-point Likert scale ranging from $1=$ strongly disagree to $5=$ strongly agree. The study model includes one independent variable viz., training and one dependent variable employee performance. Further, correlation and regression analysis were carried to assess the relationship and relative influence of independent variables (training) on the dependent variable i.e., employee performance.

\section{Analysis and Findings}

Table 2

Standard Deviation

\begin{tabular}{lccc}
\hline & & Descriptive Statistics & $\mathrm{N}$ \\
\hline & Mean & Standard Deviation & 105 \\
Training & 3.6389 & .93298 & 105 \\
Performance & 3.2901 & .60732 & \\
\hline
\end{tabular}

From the descriptive analysis of the data, it shows that the standard deviation for both the variables is less than1. According to Cohen (2003), for the normal distribution of data standard deviation must have a range of 0 to 1 . As is 
evident that the standard deviation of both the variables fall within the range, the data may be considered normally distributed and Pearson correlation analysis may also be carried to assess the relationship between variables under study.

Table 3

Training Correlations

\begin{tabular}{|c|c|c|c|}
\hline \multicolumn{4}{|c|}{ Correlations } \\
\hline & & Training & Performance \\
\hline \multirow[t]{3}{*}{ Training } & Pearson Correlation & 1 & \\
\hline & Sig. (2-tailed) & & \\
\hline & $\mathrm{N}$ & 105 & \\
\hline \multirow[t]{3}{*}{ Performance } & Pearson Correlation & $.747 * *$ & 1 \\
\hline & Sig. (2-tailed) & .000 & \\
\hline & $\mathrm{N}$ & 105 & \\
\hline
\end{tabular}

**. Correlation is significant at the 0.01 level (2-tailed).

This table exhibits the direction and strength among the dependent and independent variables. It was found that there exists a positive high correlation between training and employee performance to the extent of $74.7 \%(.747 * *$. The relationship is significant at $1 \%$ level of significance for two-tailed tests.

For hypothesis testing and studying the variable relationship regression analysis has also been carried on. The result of regression analysis by SPSS is reproduced in the following table:

Table 4

Result of regression analysis

\begin{tabular}{|c|c|c|c|c|c|c|c|}
\hline \multicolumn{8}{|c|}{$\begin{array}{l}\text { Regression Analysis } \\
\text { Coefficient }^{\mathrm{a}}\end{array}$} \\
\hline \multirow{2}{*}{\multicolumn{2}{|c|}{ Modal B }} & \multicolumn{2}{|c|}{$\begin{array}{l}\text { Unstandardized } \\
\text { Coefficients }\end{array}$} & $\begin{array}{l}\text { Standardized } \\
\text { coefficients }\end{array}$ & \multirow[t]{2}{*}{$\mathrm{T}$} & \multirow[t]{2}{*}{ Sig. } & \multirow[t]{2}{*}{$\mathrm{R}^{2}$} \\
\hline & & Std. Error & Beta & & & & \\
\hline \multirow[t]{2}{*}{1} & Constant & 1.520 & .158 & & .9634 & .000 & 559 \\
\hline & Training & .487 & .042 & .747 & 11.583 & .000 & \\
\hline
\end{tabular}

a. Dependent Variable: Performance

The regression table provides the result of the constant, coefficient of determination, $t$-value. The coefficient is the slope of the regression line and it explains that 1 unit change in the independent variable will bring how much change in the dependent variable. The coefficient of determination (R2) explains how much variation in the dependent variable is explained by the independent variable.

The regression results interpret the value of coefficient .747 that indicates $1 \%$ change in the independent variable (training) can result in $74.7 \%$ change in the dependent variable (performance). Thus, if training is increased by $1 \%$, this will result in $74.7 \%$ increase in performance. This relationship is positive and significant as shown by small pvalue. The value of the coefficient of determination (R2) is .559 that reveals training accounts to $55.9 \%$ variation in performance and this can be viewed that there might be other factors that bring a variation of $44.1 \%$ in the outcome variable. The $\mathrm{t}$ value for the hypothesis is 9.634 that training is a major predictor of performance.

\section{Conclusion}

There is enough evidence to show that employees who were trained on a regular basis are the ones who provide higher quality services to the customers. The present study examined the influence of training on performance. It further presents that organizational performance is significantly determined by training imparted to the employees or in other words training is an important antecedent of performance. Performance of an organization relies on the employee commitment which in turn depends on the HR policy of training and development. The study of the 
relationship of the employees' training with performance is important for today's managers because the modern business trends demand more efficiency, accuracy, and effectiveness in less time and cost and this can be achieved only through design, development and deployment of excellent training programs to the employees. By introducing more training programs in the organization employees become interested to get more knowledge about their jobs which eventually helps them in getting promotions among their peer groups. Since training has a significant influence on employee's work commitment and performance, it is important to reinforce and apply training as part of organizational agendas in achieving organizational goals.

It may conclusively be stated that training to a big extent leads to an improved employee's performance but still, it is not the sole factor that leads to good performance rather it is a combination of factors. A lot of future research can be done on different factors in the banking industry, but specifically in relation to employees' performance factors like training needs assessment, training programs design, development, \& deployment are important to study for knowing their effects on the resultant employees' performance in the banking industry. The role of managerial and leadership factors in employees' training and performance is also of unique importance and thus required to be investigated because a good manager or leader either increase or decrease the efficacy of training which in end affect employees' performance. The employee's compensation also has a significant effect on the performance because the employees who are not paid well often show poor performance. Growth of banking sector in India is the result of skilled manpower which is the outcome of training and development

\section{References}

Asare-Bediako, K. (2008). Professional Skills in Human Resource Management 2nded. Accra: Bediako, 7.

Baldwin, M. L., \& Johnson, W. G. (1995). Labor market discrimination against women with disabilities. Industrial Relations: A Journal of Economy and Society, 34(4), 555-577. https://doi.org/10.1111/j.1468232X.1995.tb00388.x

Boudreau, M. C., Gefen, D., \& Straub, D. W. (2001). Validation in information systems research: A state-of-the-art assessment. MIS quarterly, 1-16.

Choo, S., \& Bowley, C. (2007). Using training and development to affect job satisfaction within franchising. Journal of Small Business and Enterprise Development, 14(2), 339-352. https://doi.org/10.1108/14626000710746745

Cohen, R. A., \& Radha, H. (2003). Streaming Video. Wiley Encyclopedia of Telecommunications. https://doi.org/10.1002/0471219282.eot181

Cole, R. A. (1997). Comparison of feeding behaviour of two Brassica pests Brevicoryne brassicae and Myzus persicae on wild and cultivated Brassica species. Entomologia Experimentalis et Applicata, 85(2), 135-143. https://doi.org/10.1046/j.1570-7458.1997.00243.x

Ginsberg, A., \& Morgan, B. (2008). The Letters of Allen Ginsberg. Da Capo Press.

Heathfield, S. M. (2012). Training: Your investment on people development and retention. About. com Guide. Human Resource [on-line] Assessed on January 20, 2012 from the World Wide Web.

Ivancevich, J. M. (2010). Human Resource Management-11/E.

Jadhav, A. (2013). A study on Training and Development in Indian Banks. Management Issues \& Options, 95.

Mullins, L. J. (2007). Management and organisational behaviour. Pearson education.

Partlow, C. G. (1996). Human-resources practices of TQM hotels. The Cornell Hotel and Restaurant Administration Quarterly, 37(5), 67-77. https://doi.org/10.1016/0010-8804(96)88977-4

Pérez, A. V., Gámez, M. R., Briones, V. F. V., Viteri, C. G. V., \& Molina, L. A. V. (2018). Sustainable development seen from environmental training in university linkage. International Journal of Life Sciences, 2(1), 12-20. https://doi.org/10.29332/ijls.v2n1.75

Purohit, M. (2012). An evaluation of hrd practices followed in co-operative banks in Pune region. ACADEMICIA: An International Multidisciplinary Research Journal, 2(8), 186-195.

Ramakrishna, G., Kumar, K., Girdhar, M., \& Krishnudu, C. H. (2012). Effectiveness of Training and Development Programmes-A Case Study of Canara Bank Employees in Kurnool District. International Journal of Multidisciplinary Research, 2(4), 150-162.

Sawali, L. (2018). Drills forehand training strategy on the stroke of forehand drive ability in tennis. International Journal of Physical Sciences and Engineering, 2(2), 11-20. https://doi.org/10.29332/ijpse.v2n2.133

Sengodan, T., Sunil, B., Vaishali, R., Chandra, R. J., Nagar, S., \& Nagar, O. (2009). Formulation and evaluation of maltodextrin based proniosomes loaded with indomethacin. Int J PharmTech Res, 1(3), 517-23.

Srimannarayana, M. (2011). Measuring training \& development. Indian journal of industrial relations, 117-125. 
Sthapit, A. (2012). Strategic factors in evaluation of induction training effectiveness: an exploratory study of Nepali bank managers. EXCEL, 15.

Sulistiawati, N. P. A., Kartini, L., \& Yuliartini, M. S. (2017). Identification of development phases and changes shoots flowering orange siam plants. International Journal of Life Sciences, 1(2), 28-38. https://doi.org/10.21744/ijls.v1i2.37

Suparsa, I. N., Mantra, I. B. N., \& Widiastuti, I. A. M. S. (2017). Developing learning methods of Indonesian as a foreign language. International Journal of Social Sciences and Humanities, 1(2), 51-57. https://doi.org/10.29332/ijssh.v1n2.41

Tihanyi, L., Ellstrand, A. E., Daily, C. M., \& Dalton, D. R. (2000). Composition of the top management team and firm international diversification. Journal of management, 26(6), 1157-1177.

Wartawan, P. G. (2017). The effectiveness of the use of portfolio assessment by controlling prior knowledge to enhance scientific attitude among senior high school students. International Journal of Physical Sciences and Engineering, 1(3), 9-18. https://doi.org/10.21744/ijpse.v1i3.54 